\title{
Effect of aeration in simple photobioreactor system for biomass production of synechococcus sp. (cyanobacteria) HS-7 and HS-9 as biofuel feedstock
}

\author{
Sulthan Rafii Ardiansyah ${ }^{1}$, Aliff Muhammad Orlando ${ }^{1}$, Arif Rahman $^{2}$, Nining Betawati Prihantini ${ }^{1, *}$, and \\ Nasruddin $^{2}$ \\ ${ }^{1}$ Department of Biology, Faculty of Mathematics and Natural Sciences, Universitas Indonesia, Kampus UI Depok, Depok \\ 16424, West Java, Indonesia \\ ${ }^{2}$ Department of Mechanical Engineering, Faculty of Engineering, Universitas Indonesia, Kampus UI Depok, Depok 16424, \\ West Java, Indonesia
}

\begin{abstract}
People have been searching toward to biofuel as a prominent alternative to replace oil fuel. Microalgae biomass, specifically from the genus Synechococcus, has been used as the biofuel's feedstock as it's able to grow faster than the other groups at cyanobacteria. Strains being used were isolated from Ciseeng hot spring (HS-7) and Rawa Danau Banten hot spring (HS-9). The intensity of aeration (IA) were given as high (330 bubbles/min) and low (220 bubbles/min) to understand its influence on feedstock growth. Change in growth was observed microscopically using direct methods over fourteen days. At the end of the experiment, result demonstrate that high IA gaves rise to Synechococcus biomass density at $125,21 \times 10^{6} \mathrm{cell} / \mathrm{ml}$ and $100,63 \times 10^{6}$ cell $/ \mathrm{ml}$ for HS-7 \& HS-9 respectively. Meanwhile, low IA gaves rise to Synechococcus biomass density at $21,7 \times 10^{6} \mathrm{cell} / \mathrm{ml}$ and $10,61 \times 10^{6} \mathrm{cell} / \mathrm{ml}$ for HS-7 \& HS-9 accordingly. Positive trend also follows the growth at Synechococcus biomass with high IA, but did not apply to the system with low IA. The difference in biomass production occurred because of discrepancies in cell and nutrient distribution inside the photobioreactor system. Therefore, it implies that proper controlling of IA would affect the yielding of feedstock for producing biofuels.
\end{abstract}

\section{Introduction}

Microalgae are potential microorganisms that can be used as biofuel feedstock. It contains many components that very useful for us, one of its components are lipids [1]. The lipids can be derived into many fuels product such as bioethanol or even aviation fuel [2]. In order to produce large amounts of biofuel, biomass propagation must be done by using photobioreactor $(\mathrm{PBr})$. This system meant to be created to produce high amount biomass in short time. Photobioreactor system will provide an optimum condition for microalgae growth. This $\mathrm{PBr}$ system controlling many factors. The factors in $\mathrm{PBr}$ can be classified into physical, chemical, and biological factors. One of the physical factors is the intensity of aeration (IA) [1].

$\mathrm{IA}$ in $\mathrm{PBr}$ system are so important to supplying $\mathrm{CO}_{2}$ and agitating the system. The optimum IA could be correlated by the good growth of microalgae in the system. By using Synechococcus sp. HS-7 and HS-9, IA effect was evaluated in order to get an optimum IA for its growth. Synechococcus sp. HS-7 and HS-9 were isolated from hot spring at Ciseeng, West Java and Rawa Danau, Banten respectively. Both strains were chosen because it ability to grow faster than many other species of microalgae. Their ability to grow faster is caused by the reproduction way. As coccoid cyanobacteria,

Synechococcus sp. multiplying their cells by binary fission. This mechanism of reproduction, allow them to grow exponentially. Previous research state that Synechococcus sp. grew optimally at $20-45^{\circ} \mathrm{C}$ and $\mathrm{pH}$ ranged from 6-8, and because of that condition, the $\mathrm{PBr}$ was designed specifically for it [3]. Other recent research also shown that aeration factor is the one of the most important part of designing $\mathrm{PBr}$ system. Influence of aeration factor is classified into several subfactors such as intensity of aeration [1], air circulation pattern [4], air composition [5], etc. This research was conducted as preliminary research for designing a novel $\mathrm{PBr}$ system for coccoid cyanobacteria. This research also focused on the effect of IA on Synechococcus sp. biomass growth, in order to determining the optimal IA for the $\mathrm{PBr}$ system.

\footnotetext{
* Corresponding author: nining.prihantini@gmail.com
} 


\section{Materials and Methods}

\subsection{Designing Photobioreactor}

Simple photobioreactor $(\mathrm{PBr})$ was designed by using home materials such as PET bottle, plastic hose, and aquarium aerator. All of the components were assembled by using liquid nails and glue. Four $\mathrm{PBr}$ was assembled to contain two strains of Synechococcus sp. with different IA. As the light sources, several lamps were added to the system and set into 10000 lux for each PBr. The cage for containing the $\mathrm{PBr}$ also created in order to maintain the $\mathrm{PBr}$ in good condition.

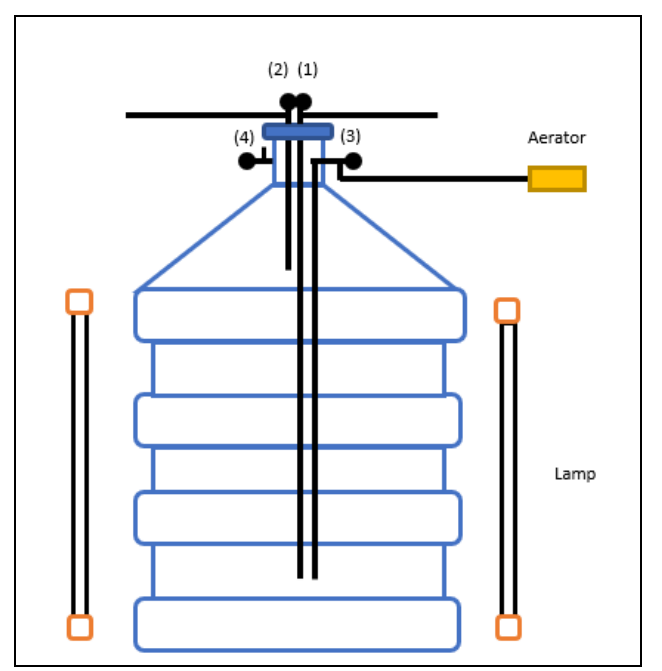

Fig. 1. Scheme of simple photobioreactor (PBr), (1): Sampling port, (2): Inoculation port, (3): Gas inlet, (4): Gas outlet

\subsection{Media Preparation and Cultivation}

Bold's Basal Medium (BBM) was chosen to be cultivation media. This media contains almost all macronutrients and micronutrients to provide nutrients for Synechococcus sp. growth [6]. The BBM media made by mixing 16 chemical components into distilled water and sterilized by autoclave. The cultivation then begin after the temperature of media was decrease. Cultivation started to make starter culture containing fresh Synechococcus sp. HS-7 and HS-9. Then the starter was incubated for one week until it ready to be move into the PBr system.

\subsection{Data Collection and Statistical Analysis}

The $\mathrm{PBr}$ system then placed in green house for 14 days. The IA then set into low IA (220 bubbles/min) and high IA (330 bubbles/min). Data was collected every 24 hours and observed directly under microscope. Complementary data such as temperature, $\mathrm{pH}$, and light intensity also collected for further research. All of the collected data then analysed by Student's T-test and descriptive statistic with $\alpha=0,05$.
Table 1. Bold's Basal Medium (BBM) composition

\begin{tabular}{|c|c|c|c|}
\hline Components & $\begin{array}{c}\text { Stock } \\
\text { Solution } \\
\left(\text { g. } L^{-1}\right. \\
\left.d H_{2} \mathrm{O}\right) \\
\end{array}$ & $\begin{array}{l}\text { Quantity } \\
\text { Used }\end{array}$ & $\begin{array}{c}\text { Concentration } \\
\text { in Final } \\
\text { Medium }\end{array}$ \\
\hline \multicolumn{4}{|l|}{ Macronutrients } \\
\hline NaNO3 & 25.00 & $10 \mathrm{~mL}$ & $2.94 \times 10^{-3}$ \\
\hline $\mathrm{CaCl} 2 \cdot 2 \mathrm{H} 2 \mathrm{O}$ & 2.50 & $10 \mathrm{~mL}$ & $1.70 \times 10^{-4}$ \\
\hline $\begin{array}{c}\mathrm{MgSO} 4 \\
7 \mathrm{H} 2 \mathrm{O} \\
\end{array}$ & 7.50 & $10 \mathrm{~mL}$ & $3.04 \times 10^{-4}$ \\
\hline K2HPO4 & 7.50 & $10 \mathrm{~mL}$ & $4.31 \times 10^{-4}$ \\
\hline KH2PO4 & 17.50 & $10 \mathrm{~mL}$ & $1.29 \times 10^{-3}$ \\
\hline $\mathrm{NaCl}$ & 2.50 & $10 \mathrm{~mL}$ & $4.28 \times 10^{-4}$ \\
\hline $\begin{array}{c}\text { Alkaline EDTA } \\
\text { Solution }\end{array}$ & & $1 \mathrm{~mL}$ & \\
\hline EDTA & 50.00 & & $1.71 \times 10^{-4}$ \\
\hline $\mathrm{KOH}$ & 31.00 & & $5.53 \times 10^{-4}$ \\
\hline $\begin{array}{c}\text { Acidified Iron } \\
\text { Solution }\end{array}$ & & $1 \mathrm{~mL}$ & \\
\hline $\mathrm{FeSO} 4 \cdot 7 \mathrm{H} 2 \mathrm{O}$ & 4.98 & & $1.79 \times 10^{-5}$ \\
\hline $\mathrm{H} 2 \mathrm{SO} 4$ & & $1 \mathrm{~mL}$ & \\
\hline \multicolumn{4}{|l|}{ Boron Solution } \\
\hline $\mathrm{H} 3 \mathrm{BO} 3$ & 11.42 & & $1.85 \times 10^{-4}$ \\
\hline $\begin{array}{l}\text { Trace Metals } \\
\text { Solution } \\
\end{array}$ & & $1 \mathrm{~mL}$ & \\
\hline $\mathrm{ZnSO} 4 \cdot 7 \mathrm{H} 2 \mathrm{O}$ & 8.82 & & $3.07 \times 10^{-5}$ \\
\hline $\mathrm{MnCl} 2 \cdot 4 \mathrm{H} 2 \mathrm{O}$ & 1.44 & & $7.28 \times 10^{-6}$ \\
\hline $\mathrm{MoO} 3$ & 0.71 & & $4.93 \times 10^{-6}$ \\
\hline $\mathrm{CuSO} 4 \cdot 5 \mathrm{H} 2 \mathrm{O}$ & 1.57 & & $6.29 \times 10^{-6}$ \\
\hline $\begin{array}{c}\mathrm{Co}(\mathrm{NO} 3) 2 \\
6 \mathrm{H} 2 \mathrm{O}\end{array}$ & 0.49 & & $1.68 \times 10^{-6}$ \\
\hline
\end{tabular}

\section{Results and Discussion}

\subsection{Power of Hydrogen $(\mathrm{pH})$ and Temperature}

During 14 days of observation, $\mathrm{pH}$ and temperature of $\mathrm{PBr}$ system were also recorded at every time the sample was taken. Data show that from $\mathrm{T}_{0}$ until $\mathrm{T}_{10}$ the $\mathrm{pH}$ of $\mathrm{PBr}$ system are constant at 6,5 and changed to 7 in the next following days. In the other side, fluctuation of temperature is not very extreme, considering the system was placed in the green house. The fluctuation of temperature is ranged from $25^{\circ} \mathrm{C}$ to $31^{\circ} \mathrm{C}$. This fluctuation still can be assumed as normal, considering the range of Synechococcus sp. optimum temperature range. Power of Hydrogen $(\mathrm{pH})$ fluctuation caused by product of Synechococcus sp. metabolism. This kind of fluctuation occurs because the residual hydrogen from the photosynthetic pathways. Hydrogen released into the system in two forms. That two forms are $\mathrm{H}^{+}$or $\mathrm{OH}^{-}$then later affecting the system. In other ways, the temperature fluctuation is caused by the environmental change outside the system. It happens because the green house still affected by climate changes. In other ways, whatever happen outside the green house, also affecting what inside it [6]. 


\subsection{Statistical Measure of Synechococcus sp. Biomass Growth}

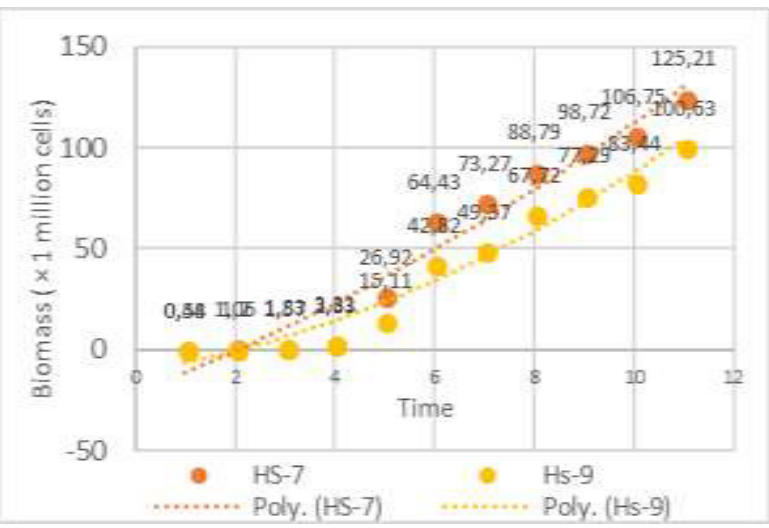

Fig. 2. Synechococcus sp. HS-7 and HS-9 growth in high IA

The main parameter of this research is how IA effecting the growth rate of Synechococcus sp. biomass. The biomass growth in high IA shown that the rate of grows are significantly increased at every sampling time. The growth rate of the Synechococcus sp. then can be expressed as mathematical equations:

$$
\begin{gathered}
Y_{l}=0,3921 x^{2}+9,438 x-21,017 \\
R^{2}=0,9501 \\
Y_{2}=0,596 x^{2}+3,9324 x-10,721 \\
R^{2}=0,9657
\end{gathered}
$$

The $\mathrm{Y}_{1}$ and $\mathrm{Y}_{2}$ are notation for biomass yield for Synechococcus sp. HS-7 and HS-9 respectively. The equations show that yields of biomass are grow along with the days (x). The biomass of Synechococcus sp. HS-7 are grow from $0,44 \times 10^{6}$ cells $/ \mathrm{mL}$ to $125,21 \times 10^{6}$ cells $/ \mathrm{mL}$ after 14 days. Along with that, the biomass of Synechococcus sp. HS-9 grow from $0,58 \times 10^{6}$ cells $/ \mathrm{mL}$ to $100,63 \times 10^{6}$ cells $/ \mathrm{mL}$ after 14 days.

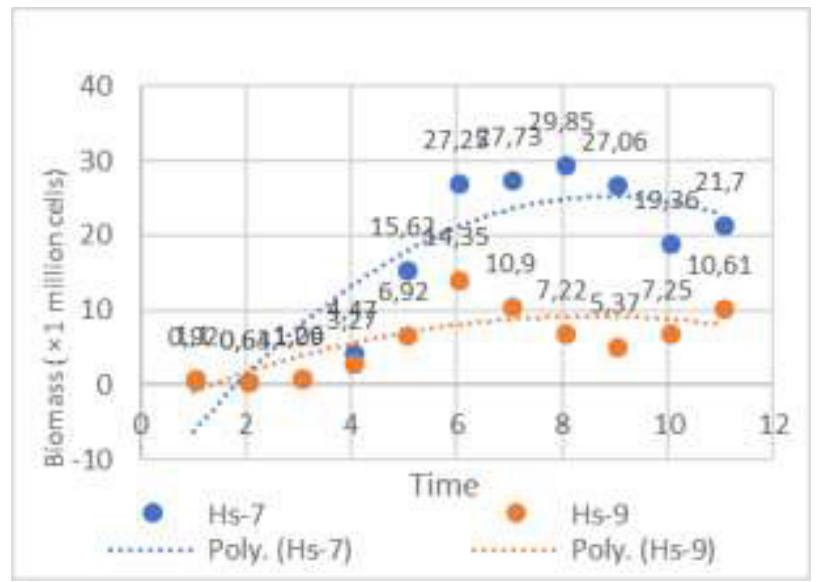

Fig. 3. Synechococcus sp. HS-7 and HS-9 growth in low IA

A bit different from the high IA, graphical trends shown that the low IA didn't give good effect on both strains Synechococcus sp. The graphic shown unstable growth that can be expressed in mathematical equations:

$$
\begin{gathered}
Y_{1}=-0,5098 x^{2}+9,0229 x-14,714 \\
R^{2}=0,7991 \\
Y_{2}=-0,1754 x^{2}+2,9983 x-3,6579 \\
R^{2}=0,5671
\end{gathered}
$$

The $\mathrm{Y}_{1}$ and $\mathrm{Y}_{2}$ are notation for biomass yield for Synechococcus sp. HS-7 and HS-9 respectively. Yields of biomass are grow along within days (x). The biomass of Synechococcus sp. HS-7 are grow from $0,92 \times 10^{6}$ cells/mL to $21,70 \times 10^{6}$ cells $/ \mathrm{mL}$ after 14 days. Along with that, the biomass of Synechococcus sp. HS-9 grow from $1,1 \times 10^{6}$ cells $/ \mathrm{mL}$ to $10,61 \times 10^{6}$ cells $/ \mathrm{mL}$ after 14 days.

Table 2. Paired sample statistic table of IA effect to biomass growth

\begin{tabular}{|c|c|c|c|c|c|}
\hline \multicolumn{6}{|c|}{ Paired Samples Test } \\
\hline & & Paired Differences & \multirow{3}{*}{$\mathbf{t}$} & \multirow{3}{*}{ df } & \multirow{3}{*}{$\begin{array}{l}\text { Sig. (2- } \\
\text { tailed) }\end{array}$} \\
\hline & & $\begin{array}{l}\text { 95\% Confidence } \\
\text { Interval of the } \\
\text { Difference }\end{array}$ & & & \\
\hline & & Upper & & & \\
\hline $\begin{array}{c}\text { Pair } \\
1\end{array}$ & $\begin{array}{c}\text { HS7-H - } \\
\text { HS7-L }\end{array}$ & 63,63743 & 3,234 & 10 & ,009 \\
\hline $\begin{array}{c}\text { Pair } \\
2\end{array}$ & $\begin{array}{c}\text { HS9-H - } \\
\text { HS9-L }\end{array}$ & 57,64845 & 3,209 & 10 & ,009 \\
\hline
\end{tabular}

\begin{tabular}{|c|c|c|c|c|c|}
\hline \multicolumn{2}{|c|}{ Paired Samples Statistics } \\
\hline & Mean & N & $\begin{array}{c}\text { Std. } \\
\text { Deviation }\end{array}$ & $\begin{array}{c}\text { Std. Error } \\
\text { Mean }\end{array}$ \\
\hline \multirow{2}{*}{ Pair 1 } & HS7-H & 53,6482 & 11 & 48,26958 & 14,55382 \\
\cline { 2 - 6 } & HS7-L & 15,9718 & 11 & 12,00334 & 3,61914 \\
\hline \multirow{2}{*}{ Pair 2 } & HS9-H & 40,2873 & 11 & 37,82815 & 11,40562 \\
\cline { 2 - 6 } & HS9-L & 6,2618 & 11 & 4,48656 & 1,35275 \\
\hline
\end{tabular}

The result from paired sample statistic shown that mean of different IA are significantly different. The high IA resulting high amount of mean rather than low IA. This data proved that variation of IA is affecting the growth of biomass.

Table 3. Student's T-Test table of IA effect to biomass growth

The results from Student's $\mathrm{T}$ test also shown differences between the effect of high IA and low IA for Synechococcus sp. growth in $\mathrm{PBr}$ system. Both pairs shown that there are differences of biomass growth between the high IA and low IA. This conclusion was made according the $t$ score that higher than $\mathrm{t}$ score from $\mathrm{T}$ tables $\left(\mathrm{T}_{(0,05 ; 10)}=1,81\right)$. 


\subsection{Measurement of Synechococcus sp. Biomass Growth}

During exponential growth (log phase), rate of increase in cells per unit time is proportional to the number of cells present in the culture at the beginning of any sampling time $\left(T_{t}\right)[6]$. The rate of growth later can be expressed as:

$$
\begin{aligned}
& d n / d t=r N \\
& N t=N_{0} e^{r t}
\end{aligned}
$$

Where $\mathrm{N}_{0}$ is the population size at the beginning of the interval, $\mathrm{N}_{\mathrm{t}}$ is population size of the end of time interval, and $r$ is proportional rate of changes. Later the $r$ value can be equated by:

$$
r=\frac{\ln \left(\frac{N t}{N o}\right)}{\Delta t}=\frac{\ln N t-\ln N t}{\Delta t}
$$

Where $\Delta \mathrm{t}$ was the length of days interval which is equivalent to:

$$
r=\mu-m
$$

Where $m$ is rate of mortality. Later, the growth rate $(r)$ value can be converted to doubling time $(k)$ measure by using this equation:

$$
\begin{aligned}
& k=r / 0,6931 \\
& k=\frac{\log 2\left(\frac{N t}{N o}\right)}{\Delta t}
\end{aligned}
$$

Based on all the equations, biomass growth in the $\mathrm{PBr}$ system later can be equated. Equations start at $\mathrm{T}_{2}$ as the beginning of the time interval and $T_{14}$ as the end of the time interval. The equations are done for all of the $\mathrm{PBr}$ system, in order to get the growth rate at all of the system. The equations are:

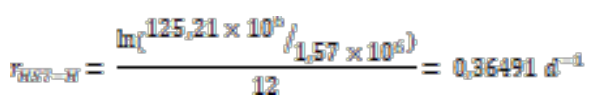

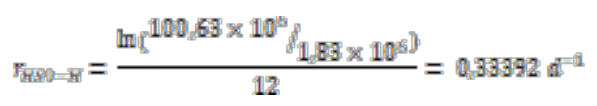

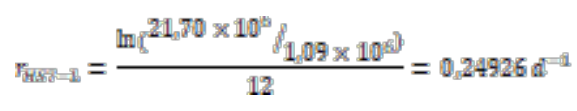

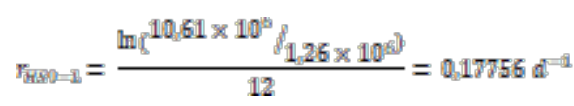

Equations shown that biomass growth rate at $\mathrm{PBr}$ system with high IA are higher rather than $\mathrm{PBr}$ system with low IA. This also followed by doubling time equations:

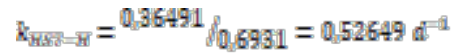

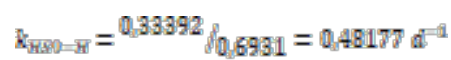

$$
\begin{aligned}
& \hat{k}_{\text {HEs }}=1
\end{aligned}
$$

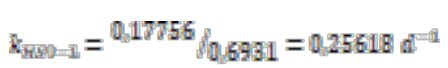

Doubling time of biomass also shown same trends, the $\mathrm{PBr}$ system with high IA shown higher doubling time rather than $\mathrm{PBr}$ system with low IA. This equation conclude that IA is really affecting their growth rate. This also shown to be connected by their physiological mechanisms [6].

\subsection{Synechococcus sp. Physiological Mechanisms}

According to all the results, IA was affecting biomass growth via many physiological pathways. But role of $\mathrm{CO}_{2}$ supply in the system and agitation caused by air injection are the most effecting factors in this research. Carbon dioxide $\left(\mathrm{CO}_{2}\right)$ was the raw material for producing energy. This $\mathrm{CO}_{2}$ will be converted into sugars via photosynthetic pathways that occurs inside Synechococcus sp. Later, sugars produced from the pathways then converted into adenosine triphosphate (ATP) or energy via cell respiration. Energy produced from this physiological pathway, are needed for cell reproduction or in other way needed for biomass growth. In $\mathrm{PBr}$ system with high IA, air injection via aeration give a lot of $\mathrm{CO}_{2}$ into the system. This $\mathrm{CO}_{2}$ later can be correlated by the energy production for their reproductive purposes [7].

Air injection via aerator also giving a mechanical effect into the PBr system. Air injection on certain IA effecting agitation process in the system. This mechanical agitation caused by air, later providing a well distribute nutrients. In this case, every cell can have the same probability to get same quantities of nutrients. This phenomenon later can be correlated to the IA. High IA will caused better nutrients distribution than the low IA, and because of that, the biomass growth in $\mathrm{PBr}$ system with high IA can be more profitable [8].

In other way, the IA also preventing self-shading phenomenon in $\mathrm{PBr}$ system. In some cases, overpopulated microalgae can cover each other. This phenomenon become bad things because it will disturb the light transmission into $\mathrm{PBr}$ system. This phenomenon also made every cell in PBr system didn't acquired same light intensity to produce sugars. Mechanical agitation caused by IA can prevent that by distributing the cells via hydrodynamics patterns. Later, the high IA can decrease the potential of self-shading significantly rather than the low IA [9]. 


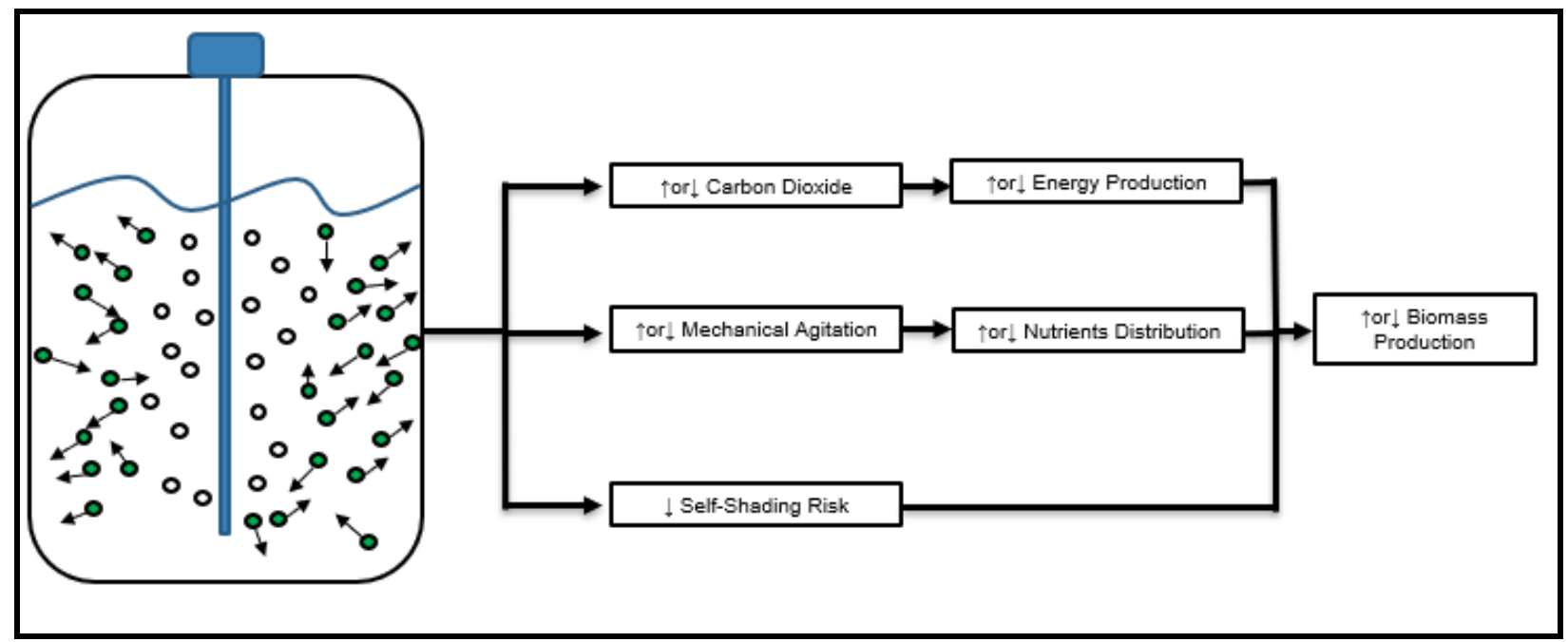

Fig. 4. General scheme of IA effect to Synechococcus sp. biomass growth in simple PBr system

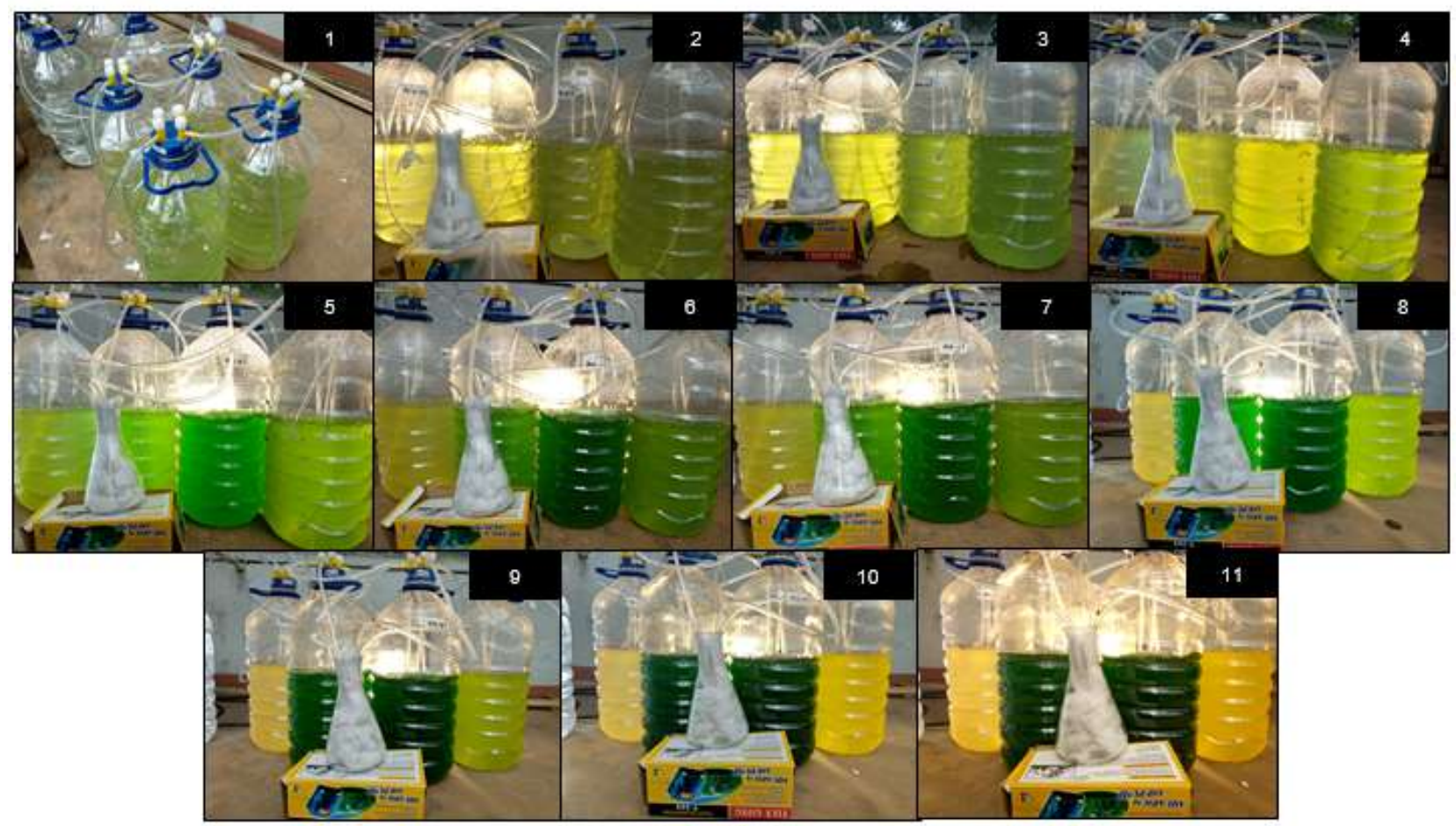

Fig. 5. Colour changing in of Synechococcus sp. in $\mathrm{PBr}$ systems. 1: colour in $\mathrm{T}_{0}, 2$ : colour in $\mathrm{T}_{1}, 3$ : colour in $\mathrm{T}_{2}, 4$ : colour in $\mathrm{T}_{3}, 5$ : colour in $T_{6}, 6$ : colour in $T_{7}, 7$ : colour in $T_{8}, 8$ : colour in $T_{9}, 9$ : colour in $T_{10}, 10$ : colour in $T_{13}, 11$ : colour in $T_{14}$

Change in biomass concentration caused by the physiological mechanisms are showed macroscopically by the changes of culture colours. Figure 5 showed that colours in PBr systems with high IA (two in the middle) are changing in every time of sampling. The colours of both Synechococcus sp. HS-7 and HS-9 biomass, are changed from the light green into very dark green. This change of colours is indicating the rises of biomass concentration. In other ways, both Synechococcus sp. HS-7 and HS-9 biomass concentration in $\mathrm{PBr}$ systems with low IA, are decreased gradually. These facts are showed by discoloration of biomass colours from light green into yellowish. This discoloration also indicating that the biomass inside the $\mathrm{PBr}$ systems are mostly dead because of $\mathrm{CO}_{2}$ deficiency.

\section{Conclusions}

Intensity of aeration (IA) does have effect to biomass growth of Synechococcus sp. Both strains (HS-7 and HS9) show results that high IA have a good impact for increasing biomass production. This preliminary research shown that further research for determining an optimum IA was required for developing photobioreactor design. This research also prove that simple materials can be used for developing a costefficient photobioreactor.

This research was funded by Hibah Publikasi Internasional Terindeks untuk Tugas Akhir Mahasiswa (Hibah PITTA) 2018 to Nasruddin, grant no. 2498/UN2.R3.1/HKP.05.00/2018. 


\section{References}

1. R. Slade \& A. Bauen. Micro-algae Cultivation for Biofuels : Cost, Energy Balance, Environtmental Impacts, and Future Prospect. Biomass \& Bioenergy 53, 29-38 (2013)

2. J. Milano, H. C. Ong, H. H. Masjuki, W. T. Chong, M. K. Lam, P. K. Loh, V. Vellayan. Microalgae Biofuels as an Alternative to Fossil Fuel for Power Generation. Renewable and Sustainable Energy Review 58, 180-197 (2016)

3. J. Yu, M. Liberton, P. F. Cliften, R. D. Head, J. M. Jacobs, R. D. Smith, D. W. Koppenaal, J. J. Brand, H. B. Pakrasi. Synechococcus elongatus UTEX 2937, A Fast Growing Cyanobacterial Chassis for Biosynthesis Using Light and $\mathrm{CO}_{2}$. Scientific Reports 8132, 1-10 (2015)

4. E. Molina, J. Fernandez, F. G. Acien, Y. Chisti. Tubular Photobioreactor Design for Algal Cultures. Journal of Biotechnology 92, 113-131 (2001)
5. V. R. Naira, D. Das, S. K. Maiti. Designing a $\mathrm{CO}_{2}$ Supply Strategy for Microalgal Biodiesel Production Under Diurnal Light In a Cylindricalmembrane Photobioreactor. Bioresource Technology 250, 936-941 (2018)

6. R. A. Andersen. Algal Culturing Techniques. Elsevier Academic Press, 589 (2005)

7. C. S. Ting, J. King, S. W. Chisholm. Cyanobacterial Photosynthesis In The Ocean: The Origins and Significance of Divergent LightHarvesting Strategies. TRENDS in Microbiology 842, 1-9 (2002)

8. S. R. Ronda, C. S. Bokka, C. Kiteneni, B. Rijal, P. R. Allu. Aeration effect on Spirulina platensis growth and $\gamma$-Linolenic acid production. Brazilian Journal of Microbiology 43, 12-20 (2012)

9. E. Sforza, B. Gris, C. E. D. F. Silva, T. Morosinotto, A. Bertucco. Effects of Light on Cultivation of Scenedesmus Obliquus in Batch and Continuous Flat Plate Photobioreactor. Chemical Engineering Transaction 38, 211-216 (2014) 